\title{
From the Pleven Plan to the Single European Act: Notes on the European security, defense and foreign policy
}

\author{
Matteo Antonio Napolitano, PhD \\ Niccolò Cusano University \\ Rome (Italy)
}

\begin{abstract}
The present paper, withoutclaiming to be exhaustive, aims to analyze andinsert in the international dynamics the main phases of construction of the European security, defense and foreign policy.Starting from the Pleven Plan and the shared need to rethinkthe European structureunder new key conditionsafter the Second World War, the essay will take into consideration the difficulties and criticalities encountered in trying to provide a unitary identity to the crucial issue of European defense, up to the Single European Act.
\end{abstract}

Keywords: European integration, Foreign policy, Defense, Security, International relations.

\section{From the Pleven Plan to the Western European Union (WEU)}

In the aftermath of the end of the Second World War, there was a general and shared need to rethink the European structureunder renewed conditions and with the awareness of the need to leavethe past behind, despite the enormous difficulties and the heavy legacy of those years in which«l'unitàeuropeasirealizzònellaviolenza, attraverso le conquiste di Hitler e secondo le idee-forza dellanazione e dellarazza» (Mammarella, 1994: 12).

One of the most critical issues of this delicate phase was the reorganization ofa defense and security system, that was unsteady during the initial phase of the Cold Warand then affected by the mutual interests of the United States and the Soviet Union, and «l'obiettivo di coinvolgeretuttiipaesidell'Europaoccidentale, compresa la Germania» (Aliberti and Malgeri, 1999: 725).

Ashighlighted by Antonio Varsori (2009: 1), if «nella fase iniziale della guerra fredda le potenze occidentali non parvero percepire la politica staliniana come una minaccia di carattere militare» and, on aproposal of the British authorities, «la vaga ipotesi di alleanza occidentale» (Varsori, 2009: 2) wasformulated in January 1948and paved the way for both the BrusselsPact (Varsori, 1988), and «al complesso processo politico-diplomatico che nell'aprile del 1949 trovò completamento con la firma del trattato di Washington, il quale istituiva il Patto atlantico» (Varsori, 2009: 2),then«tra la metà del 1949 e i primi mesi del 1950 la situazione subì [...] una rapida trasformazione»(Varsori, 2009:3).

When, on August 29, 1949, «fusperimentata la prima bombasovietica a fissione» (Longo e Silvestrini, 1987: 28) - key event for the end of the US atomic monopoly - and, on the $1{ }^{\text {st }}$ October of the same year, the birth of the People's Republic of China was proclaimed in Beijing, the general picture became more unstable but, at the same time, more defined.To complete this articulated phase of change in the international context, on $25^{\text {th }}$ June 1950the attack of North Korean troops to South Korea took place. It was in this set of contingencies that the Korean crisis«[fece] apparire d'un trattoindispensabileilrapidopotenziamentodelladifesaeuropea»(Calandri, Guasconiand Ranieri, 2015: 66), since not only it resembled the German situation butalso because there was a strong belief that Moscowhad responsibilities over the affair. For this specific and fundamentalpurpose, asnoted by Daniela Preda (1994: 49), «il nodo da sciogliere riguardava ancora una volta la sovranità tedesca» - sureenough - «nel clima della guerra fredda, e soprattutto dopo l'inizio della guerra di Corea nel giugno del '50, gli americani auspicavano per ovvi motivi il riarmo della Germania. Per ragioni altrettanto ovvie i francesi cercavano d'impedirlo, ma non ne avevano il potere. Anche in questo caso, solo un cambiamento radicale di prospettiva avrebbe permesso di superare l'ostacolo». With the launch of the Schuman Plan in May 1950, whosemain lines weredictated by functionalistEuropeanism (Bossuat and Wilkens, 1999; Varsori, 2003) by Jean Monnet (Majone, Noël and Van denBossche, 1989; Audisio and Chiara, 1999; Fransen, 2001), the French strategy on the Germanquestiontook a precise directionsince «oltre che un progetto economico - the Plan - era anche una risposta alla prospettiva della restituzione di una piena sovranità politica, ma anche militare [a]lla Repubblica Federale Tedesca» (Calandri, Guasconi and Ranieri, 2015: 66). 
Seen the refusal to include the German rearmament in the Atlantic framework and the need to hypothesize an alternative route, keeping in mind that it was necessary to indulge «both the Americans' desire for progress towards European unity and their intention to consolidate the role of the new German democracy on their eastern borders» (Gilbert, 2010: 173), the French proposed the creation of a European army, linked to common political institutions(Preda, 1990).

The initiative, also in this case on the advice of Jean Monnet, was adopted by Prime Minister René Pleven and collected in a project - announced at the French National Assembly on 24th October 1950 and called precisely Pleven Plan - aimed at «[...] inserireicontingentimilitaritedeschirichiestidalladifesadell'Europa in un esercitoeuropeointegrato al livello di unità le piùridottepossibili (in ognicasoinferiorialladivisione) e gestito da istituzionisovranazionali» (Preda, 1994: 49). For this purpose, the formation of the integrated army, consisting of several national units «affiancatealledivisioni dei paesidell'AlleanzaAtlantica» (Calandri, Guasconiand Ranieri, 2015: 68), under the US command and financed by a common budget, had to be complementary to the creation of a «ministeroeuropeodellaDifesa, responsabile di fronte a un Consiglio dei ministri e a un'Assemblea quelladell'istituendacomunità carbo-siderurgica» (Calandri, Guasconiand Ranieri, 2015: 67). The parallel process of negotiations for the ECSC(European Coal and Steel Community) would have had to affect the initial effectiveness of the Pleven Plan since the latter «avrebbepresoil via solo dopo la firma del Trattato CECA e avrebbecoinvoltoimedesimipartecipanti, più la Gran Bretagna» (Calandri, Guasconiand Ranieri, 2015: 68).

The ambitious system structured by France led, in February 1951, to the inauguration of the Paris Conference for the Organization of the European Army, where the Countries of Benelux, Italy, Federal Republic of Germany and, later, the Netherlands gathered to study forms and contents of the desired European Defense Community (EDC).Despite the efforts and the historical context - in fact «la veraoccasione per misurareilgrado di omogeneità e di concordia visto chefino ad allora le propostefrancesi non erano state oggetto di una trattativaformale» (Caviglia and Gionfrida, 2009: 23) -, the French draft of the Treaty, on one hand,did not discard the prejudices regarding the issue of conferring equal rights to Germany and, on the other, raised someconcerns among the parties, that were fearful about the excess of closure in a bilateral front France/Germany andabout the external balances that could influence the environment of the negotiations.

A turning point in the impasse and mutual distrust was reached, in April 1951, through the signing of the ECSC Treaty and the decisive change that it implied both for the international position of the Federal Republic of Germany and for the adoption of a long-term vision.The possibilities offered to Germany with the Treaty, especially the reconstruction of an independent Foreign Ministry and the recognition of equal rights in their relations with France, in fact, gave new life to the Paris Conference which - with the backup and influence of the United States - marked the following stages until the signing of the EDC Treaty, that took place in the French capital on $27^{\text {th }}$ May 1952.However, «dopo la firma delTrattato iniziava una altalena di successi, speranze ecrisi per laCED e la CPE» (Caroli, 2018: 115-116).

In addition to representing a significant step forward for military and strategic issues, the construction of the European Defense Community was closely linked to the «prima formulazione di un progetto di unione politica» (Guerrieri, 2009: 165). The main promoter of this initiative was the Italian Prime Minister, Alcide De Gasperi (Preda, 2004; Craveri, 2006), persuaded by the need to combine the defensive aspects with the birth of a solid European Political Community.Following this idea, «grâce à son initiative, dans le traité CED [...] fut inséré l'article 38, qui conférait à l'Assemblée parlementaire de la CED, une fois créée, la tâche d'entreprendre l'étude d'un projet de communauté politique, inspiré par le principe de la séparation des pouvoirs et comportant un système bicaméral de représentation» (Guerrieri, 2007: 92). The mechanism of Article 38 was actually anticipated and delegated by the governments of the Six Countries to the Common Assembly of the ECSC which, for the occasion, took the name of ad hoc Assembly. «L'Assemblea della CECA - aswritten by Umberto Morelli -, integrata da nove membri [...], elesse una commissione costituzionale, presieduta da Heinrich von Brentano, per preparare il progetto di statuto della Comunità Europea; l'aggettivo "politica" era stato lasciato cadere al fine di sottolineare l'unicità della Comunità, che non si affiancava a quelle esistenti, ma le incorporava» (Morelli, 2009: 8). The project approved on 10th March1953«fondeva insieme diversi elementi, creando un'organizzazione diversa sia da una confederazione sia da uno Stato federale», though, «sul piano istituzionale l'influenza dell'impostazione federalista [...] si dimostrava assai rilevante» (Guerrieri, 2009: 168-169).

After the signature and despite the wide debate that was opened on the nature of the project and on the institutional architecture that it envisaged, the phase of parliamentary ratifications resulted in the definitive collapse of De Gasperi's aspirations on political unity. «L'ultima spina di De Gasperi» (Quagliariello, 2004), and of the entire EDC plan. 
In particular, it was decisive «l'affossamento del trattato Ced da partedell'Assembleanazionalefrancese, il 30 agosto 1954» (Guerrieri, 2009: 169) and equally importance had the changed international context following the death of Stalin, in March 1953, the resulting weakening of the tension between the blocs and the development of the war in Indochina.

The blow was very hard, but in the following months an alternative strategy was put in place, aimed at filling the gap left over from four years - from 1950 to 1954 -that had been lived with great intensity and great planning fervor, in a Europe undergoing total reconstruction.It was decided not to abandon the whole initiative in the field of security and defense and already in October 1954 the Countries of the Atlantic Pact completed the definition of the «soluzione di ricambio» (Calandri, Guasconi e Ranieri, 2015: 77).Gathered in London, «i Paesi firmatari del Patto di Bruxelles [...] con Italia, Repubblica federale di Germania [...], Canada e Stati Uniti, [...] concordarono la trasformazione della Western Union in Western European Union - Unione Europea Occidentale (Ueo), invitando nel contempo Italia e Repubblica federale di Germania a sottoscrivere il relativo trattato, opportunamente emendato. La formalizzazione avvenne il successivo 23 ottobre a Parigi, dove i rappresentanti dei sette Paesi europei firmarono il "Trattato di Bruxelles modificato"» (Camporini, 2007: p. 77).

Although the underlying character waspolitical-formalrather than military, and the structure downsized - compared to the European Defense Community -, the WEU represented a very important point of connection for the subsequent developments of relations in the Old Continent, fulfilling the role of «congiunzionetra le struttureeuroatlantiche e quelle dei Paesiaderenti al Mercato comuneeuropeo prima e in seguitoallaComunitàeuropea»(Camporini, 2007: p. 77).

\section{Between the Treaties of Rome and the end of the '70s}

After the events related to the failure of the EDC, the desire of redemption of European Countries became tangible - as well as in the formation of the WEU - in the Relaunch of Messina in 1955, strongly supported by Gaetano Martino (Battaglia, 2000), and in the Val Duchesse Negotiations of 1956 (Nonis, 1959).These two central moments constituted the preparatory phase that led to the negotiations and then to the signing of the Rome Treaties of 1957, establishing EEC (European Economic Community) and EURATOM (European Atomic Energy Community).

The greater attention paid to economic integration and to energy objectives did not mean, in any case, the total abandonment of any prospect of political unity. As noted by Riccardo Caimmi, especially in relation to the increasingly pressing role of NATO and the intent of the Six to use atomic energy for civilian purposes, «alla soglia degli anni sessanta la logica stringente dei blocchi non permetteva [...] alle democrazie europee alcun tentativo di reale emancipazione dalla potenza guida americana ed in quest'ottica debbono essere visti anche i rapporti tra NATO e UEO, organizzazione di difesa, quest'ultima, destinata a vivere quel lungo periodo di torpore che caratterizzò, salvo sporadici sussulti, tutti i progetti politici o militari prettamente europei, aventi un ampio respiro, per quasi tre decenni» (Caimmi, 2004: 77).

Although the obstacles were difficult to overcome, in the period between the late Fifties and the Sixties it was the French President Charles de Gaulle that put into actioninitiatives of greatest interest and criticality. In fact,alreadyin 1960, he «pose direttamente la questione del "prolungamento politico dell'attività della Comunità", avanzando un progetto di coordinamento e armonizzazione delle politiche estere, di sicurezza e di difesa dei governi europei, basato su un impianto confederale, - corresponding to the - sua visione di un'Europa degli Stati» (Guasconi, 2015: 33).

Following this line, the two Fouchet Plans, from the name of the French diplomat, president of an intergovernmentalcommissioncharged with drawing up proposals for closercooperationbetween the members of the EEC in varioussectors - including defense and the militarysphere -, significantlyrepresented «l'aspirazione francese ad assumere la guida di tale raggruppamento europeo occidentale, cosa che avrebbe consentito a de Gaulle di porsi su un piano di parità rispetto alla Gran Bretagna e agli Stati Uniti all'interno del sistema occidentale» (Varsori, 2007: 31).Although the two Plans were presented at different times, the first in 1961 and the second in 1962 (Bloes, 1970; Caraffini, 2010), and both met the strong perplexities of the other Countries, the basic substance remained consistent with the General's approach. Charlesde Gaulle,in fact, did not feel confident in carrying out a process of European integration that would not follow the State model and, consequently, he did not want to consider any federal option. Moreover, he strongly desired to build a Europe that had to be politically and militarily independent from the Atlantic Alliance and USA, «checontinuavano a mantenereneiriguardidell'EuropaOccidentaleilmassimo interesse» (Caimmi, 2004: 82).

After de Gaulle's withdrawal from the political scene and the conclusion of the phase of which he was the undisputed main character, new important scenarios were arising and alsothe French political line itself, with the arrival of Georges Pompidou, undertook a more proactive approach. 
Inaugurating this new course, balancedbetweenelements of continuity and instances of change, it was the new French Prime Minister to announce «la decisione di organizzare un vertice dei capi di Stato e di governo dei sei paesi membri della Comunità, che si sarebbe tenuto all'Aja, il $1^{\circ}$ e 2 dicembre 1969» and to indicate «nel noto trittico, completamento [...], approfondimento [...] e allargamento, le direzioni del rilancio» (Calandri, Guasconi e Ranieri, 2015: 150).In practice, the summit did not register any radical change because the intergovernmental method, the centrality of the State element and the leadership of France and Germany were confirmed- with Willy Brandt on the front line together with Pompidou -, and little space was left to the European institutional participants.

For the purposes of this work, it is necessary to pay attention to the issues that arose in The Hague and that subsequently involved the so-called "deepening" of the cooperation relations among the members of the Community. The final public statement of The Hague Council, with a view to greater legitimization of the EEC at international level, assigned to the Davignon Committee - so named because of the presidency of Étienne Davignon, it was composed of the political directors of the Foreign Ministries of the Six - the task of drawing up a program for political unification with a view to enlargement.The Committee's work highlighted the differentperceptionsregarding the development of European Political Cooperation (EPC), a tool designed to «consentire ai Capi di Stato e/o di Governo degli Stati membri di poter interloquire anche riguardo argomenti che, pur non rientrando tra le competenze assegnatesi dall'organizzazione, rivestivano importanza ai fini dell'integrazione e dell'unificazione europea» (Caimmi, 2004: 88). The themes of common foreign policy, which included defense and security, were fundamental, but their specific mention was carefully avoided.As highlighted by Jeremi Suri, despite the internal resistance, in October 1970 « the European Six immediately accepted the Davignon Report, initiating consultative meetings among their foreign ministers four times each year. Lower-level foreign ministry officials from each Country met monthly to follow developments and formulate common policies. New informal coordinating mechanisms also took shape at the ambassadorial level [...]. The implementation of the Davignon Report reinforced a growing sense that a Common European foreign policy was emerging, and it provided the rudimentary institutional structure to make it become a reality» (Suri, 2008: 54).

The approval of the Davignon Report led to a significant increasingof the frequency of meetings, consolidating the contingent validity of this mode of consultation, but, despite the positive data, the speakers nevertheless proved to be aware of the fact that the results, although consistent with the premises of the intergovernmental method, were neither satisfactory nor in line with the need to effectively merge singularities to gain international weight.Aswritten by Clementi (2004: 55), «il rapporto presentato dal primo ministro belga Leo Tindemans nel dicembre 1975, e che da lui prese il nome, conteneva a chiare lettere la consapevolezza di questo limite».

Furthermore, this Report was triggered by a changed context after the summit of the Heads of State and Government of the Nine in December 1974 - after Great Britain, Ireland and Denmark joined the Community -:important perspectives were taken into account, such as the institutionalization of the European Council to coordinate the action of the EEC and the EPC, the proposal to give the European Parliament more powers and the choice of the majority method for some subjects.

During thesameyears the Conference on Security and Cooperation in Europe (CSCE) and the Helsinki Process, which «diede ai governi della Comunità l'occasione di cominciare ad agire come soggetto unitario della diplomazia europea» (Attinà, 2002b: 32; 2002a), Tindemans indicated for foreign policy and defense a veryclearpath to follow, to be built on «almeno tre passi radicali: l'abolizione della distinzione fra la Cee e la Cpe; l'inclusione fra le attività comuni delle questioni militari, concepite con un approccio che ne tenesse presenti le dimensioni economiche e politiche; l'inserimento di un obbligo legale, per i paesi membri, a giungere a posizioni comuni e, di conseguenza, l'abolizione del diritto di veto degli stati» (Clementi, 2004: 56). Although Tindemans' proposal was pragmatic and broad, it encountered general institutional distrust and was finally abandoned in October 1981, when European Governments decided to draft another document, the London Report.

\section{The '80s: Delors and the Single European Act}

In the difficulties of building a European defense, in this phase of bipolarity between the Seventies and the Eighties, the only certainty was still constituted by the alignment with the USA, «la difesadell'Europa - in fact - era assicuratadalla NATO: era la difesacontro la minacciasovietica»(Clementi, 2004: 61).

In spite of some procedural change and in the framework of the involvement of the community institutions, the excessive cautiousness of the London Report was the result of the climate of widespread distrust of a political union capable of ensuring effective control over foreign policy, defense and security. Furthermore, the adverse economic situation due to the oil crises of the Seventies created greater restraints on the transfer of sovereignty.The fear of losing control proved to be stronger than any unitary perspective. 
To demonstrate this tendency, the oppositions to the Genscher-Colombo Plan (Levi, 1982; Guasconi, 2015), very close to the conclusions of the Tindemans Report, confirmed the downward trend of the member Countries, unable to go beyond the solemn declaration of Stuttgart in June 1983 which, despite the high-sounding tones, confirmed the line reached with the London Report without substantial progress.

After the decision to relaunch the WEU as a European security and defense pillar, matured between Paris and Rome in 1984, with the arrival of Jacques Delors to the presidency of the Commission, in 1985, the situation seemed to be moving towards new unitary dimensions both on the economic plan, and on the political level.At first, however, the impasse once againrepresented the starting point of the dialoguebecause «mentre il Libro bianco - presentato dalla stessa Commissione Delors per completare, entro il 1992, il mercato interno e per dare una forma organica alle volontà di liberalizzazione - andava incontro alle attese della generalità dei paesi della CEE, le proposte del comitato Dooge imperniate sulla riforma delle istituzioni e sull'idea di dover dare i natali all'Unione Europea partendo da un nuovo trattato, da costruire tramite una Conferenza intergovernativa - raccoglievano l'adesione di una maggioranza soltanto degli Stati membri» (Rapone, 2015: 94).

The major opposition to the Dooge committee came from the British positions, alsoshared by Denmark and Greece, and in particularthe line taken by Margaret Thatcher, opposed to any compromise on the autonomy of the States despite a vision «centrata sull'implementazione del mercato comune, sulla cooperazione militare in sede Nato, così come sul ruolo guida degli Stati Uniti in campo occidentale» (Pondrano Altavilla, 2016: 192). Theseresistanceswereovercome in June 1985 when, within the Milan European Council, «Bettino Craxi, che presiedeva la riunione, mise ai voti la proposta di indire una $\mathrm{C}$ [onferenza]I[nter]G[overnativa] per la preparazione di un trattato sulla cooperazione nella politica estera e di sicurezza e per la definizione delle modifiche ai trattati vigenti [...]» (Rapone, 2015: 94). The result of the vote decreed, for the first time in a European Council, the prevalence of a majority position over that of a minority:«la propostapassòinfattinonostantel'opposizionedella Thatcher, del premier conservatoredanesePoul Schlüter e del greco Papandreou»(Rapone, 2015: 94).

The existence of the opposition did not prevent, in September 1985 in Luxembourg, the opening of the work for the Intergovernmental Conference which not only saw the participation of the same Countries in disagreement, but also the clear prevailing of the compromise provision by the majority, especially on the Paris-Bonn axis: from the negotiations and from these premises came the Single European Act, signed on February 1986 and entered into force in July 1987.Aspointed out by Piero Graglia, «l'Atto unico segnò una sorta di "ripresa" dell'Europa comunitaria [...] infatti, [...] si introdussero importanti modifiche procedurali (per snellire i processi decisionali) - and - si potenziarono gli strumenti per l'attuazione delle politiche comuni [...]» (Graglia, 2005: 26).

In addition to the innovations on the economic and institutional level (Panebianco, 1988), the community relaunch of the Single European Act also passed, for the first time after the EDC's attempt in1950s, by the approval«con la forma giuridica del trattato [di] clausole relative alla politica estera e di sicurezza» (Clementi, 2004: 60).In fact, as a formalresult of a «lunga lista di rilevanti aree di collaborazione in materia di politica estera» (Calandri, Guasconi and Ranieri, 2015: 215)drawn up by the Foreign Ministers on the occasion of the signature, the Single European Act «specificava gli obiettivi di proteggere i "comuni interessi e l'indipendenza dell'Europa" e di "contribuire alla pace e alla sicurezza internazionale", e stabiliva formalmente la Cpe come parte integrante della collaborazione fra i membri della Cee» (Clementi, 2004: 60), gettingrid of the rigid and limitingseparationbetween EPC and Community policies.Although the institutionalization of European PoliticalCooperationmeant, ratherthan an explicit union, the recognition of the effectiveness of the harmonizationmethod - by means of intergovernmentalconsultations -, this instrumentallowed «alla CEE di muoversi con maggiore disinvoltura sullo scenario internazionale, rafforzando la dimensione delle relazioni esterne» (Calandri, Guasconi and Ranieri, 2015: 216).

If the Single European Act represented a moment of reform of the European structures and of consolidation of a longterm path, a radical rethinking of the objectives became necessary after the three years 1989-1991since the end of the bipolarism brought a profound upheaval of theEuropean atlas «and liberated member states from the politicizing shadow of Cold War rivalries» (Bickerton, 2012: 171).

\section{Reference List}

Aliberti, G.,\&Malgeri, F. (1999). Due secoli al Duemila. Transizione - Mutamento - Sviluppo nell'Europa contemporanea (1815-1998). Milano: Edizioni Universitarie di Lettere Economia Diritto.

Attinà, F. (2002a). La Politica estera e di sicurezza comune (PESC).In Attinà, F, Longo, F., Monteleone, C., Panebianco, S.,\& Rosa, P. (Eds.), La politica di sicurezza e difesa dell'Unione europea. Il cammino europeo dopo il trattato di Amsterdam(pp. 13-30). Gaeta:Artistic\&Publishing Company. 
Attinà F. (2002b).La politica europea di sicurezza e difesa (PESD).In Attinà, F, Longo, F., Monteleone, C., Panebianco, S.,\& Rosa, P. (Eds.), La politica di sicurezza e difesa dell'Unione europea. Il cammino europeo dopo il trattato di Amsterdam(pp. 31-60). Gaeta:Artistic\&Publishing Company.

Audisio, G. \& Chiara, A. (1999). I fondatori dell'Europa Unita secondo il progetto di Jean Monnet. Robert Schuman. Konrad Adenauer. Alcide De Gasperi. Cantalupa (Torino):Effatà Editrice.

Battaglia, R. (2000). Gaetano Martino e la politica estera italiana, 1954-1964.Messina: EDAS.

Bickerton, C.J. (2012). European Integration. From Nation States to Member States. Oxford: Oxford University Press.

Bossuat, G., \& Wilkens, A. (Eds.) (1999).Jean Monnet, l'Europe et les chemins de la paix. Actes du Colloque de Paris du 29 au 31 mai 1997 organise par l'Institut Pierre Renouvin de l'Universite Paris-I/Pantheon Sorbonne et l'Institut historique allemand de Paris.Paris: Publications de la Sorbonne.

Caimmi, R. (2004). L'identità di sicurezza e difesa europea. Il percorso storico. Siena: Cantagalli.

Calandri, E., Guasconi, M.E.\& Ranieri, R. (2015). Storia politica e economica dell'integrazione europea. Dal 1945 a oggi. Napoli: EdiSES.

Camporini, V. (2007). Lo sviluppo della politica europea nel settore della sicurezza e della difesa. Radici, evoluzioni e prospettive.InPföstl, E.(Ed.), La creazione di una zona di pace e stabilità attorno all’Unione europea(pp. 69-112). Roma: Editrice Apes.

Caroli, G.(2018). Dal Piano Pleven alla CED. Perplessità e timori alla Conferenza di Parigi per l'Esercito europeo (19511952). Europea, 2, 65-117.

Caviglia, D. \& Gionfrida, A. (2009). Un'occasione da perdere. Le Forze Armate italiane e la Comunità Europea di Difesa (1950-54). Roma: Editrice Apes.

Clementi, M. (2004). L'Europa e il mondo. La politica estera, di sicurezza e di difesa europea. Bologna: il Mulino.

Craveri, P. (2006). De Gasperi. Bologna: il Mulino.

Fransen, F.J. (2001). The Supernational Politics of Jean Monnet. Ideas and Origins of the European Community. Westport, Connecticut - London: Greenwood Press.

Gilbert, M. (2010). Partners and Rivals: Assessing the American Role.In Kaiser, W. \& Varsori, A. (Eds.), European Union History. Themes and Debates (pp. 169-189).Houndmills: Palgrave Macmillan.

Graglia, P.S. (2005). L’Unione europea. Bologna: il Mulino.

Guasconi, M.E. (2015). Il Piano Genscher-Colombo.In Piccardo, L.(Ed.), L'Italia e l'Europa negli anni Ottanta. Storia, politica, cultura(pp. 33-46). Milano: FrancoAngeli.

Guerrieri, S.(2007). L'Italie et la construction européenne: de la naissance de la CECA au traité de Maastricht. Parlement[s], 3, Hors-série, pp. 89-101.

Guerrieri, S. (2009). Il contributo degli europarlamentari italiani ai progetti di unione politica: dall'Assemblea ad hoc al progetto Herman (1952-1994).In Craveri, P.\& Varsori, A. (Eds.), L’Italia nella costruzione europea. Un bilancio storico (1957-2007) (pp. 165-185). Milano: FrancoAngeli.

Levi, L. (1982). I progetti di riforma delle istituzioni comunitarie. Pavia: Editrice Libera Associazione "Il Federalista".

Longo, G.,\& Silvestrini, V. (1987). L'atomo militare. Tecniche, strategie, storia e prospettive. Roma: Editori Riuniti.

Majone, G., Noël, E., \& P. Van Den Bossche, P. (Eds.)(1989). Jean Monnet et l'Europe d'aujourd'hui.Baden-Baden: Nomos.

Mammarella, G. (1994). Imparare l’Europa. Bologna: il Mulino.

Morelli, U. (2009). I progetti costituzionali di origine parlamentare nel processo di integrazione europea prima della dichiarazione di Laeken.In Bilancia, P., \& D’amico M.(Eds.), La nuova Europa dopo il Trattato di Lisbona (pp. 1-26). Milano: Giuffrè.

Nonis, F.E. (Ed.) (1959). Dal Piano Marshall alla Comunità economica europea. Roma: Banco di Santo Spirito.

Panebianco, M. (1988). L'Unione europea secondo l'Atto Unico europeo. Napoli: ISVEIMER.

Pondrano Altavilla, G. (2016). L'unità europea nel pensiero di Margaret Thatcher: i discorsi dell'Aia e di Bruges. Europea, 1, pp. 191-204.

Preda, D. (1990). Storia di una speranza. La battaglia per la CED e la Federazione Europea nelle carte della delegazione italiana (1952-1954). Milano: Jaca Book.

Preda, D. (1994). Sulla soglia dell’Unione. La vicenda della Comunità Politica Europea (1952-1954). Milano: Jaca Book.

Preda, D. (2004). Alcide De Gasperi federalista europeo. Bologna: il Mulino.

Quagliariello, G. (2004). La Ced, l'ultima spina di De Gasperi. Ventunesimo secolo, III, 5, pp. 247-286.

Rapone, L. (2015). Storia dell'integrazione europea.Roma: Carocci.

Suri, J. (2008). Henry Kissinger and the reconceptualization of European security, 1969-75.In Wenger, A.,Mastny, V.,\&Nuenlist, C. (Eds.), Origins of the European Security System. The Helsinki process revisited, 1969-75 (pp. 4664). London and New York: Routledge.

Varsori, A. (1988). Il Patto di Bruxelles (1948): tra integrazione europea e alleanza atlantica. Roma: Bonacci.

Varsori, A. (2003). La Gran Bretagna e l'Europa dalla CED alla richiesta di adesione alla CEE.In Craveri, P.,\& Quagliariello, G.(Eds.), Atlantismo ed Europeismo(pp. 521-542). Soveria Mannelli: Rubbettino.

Varsori, A.(2007). Gli anni Sessanta: la crisi della NATO.In Del Pero, M.,\& Romero, F. (Eds.), Le crisi transatlantiche. Continuità e trasformazioni(pp. 25-44). Roma: Edizioni di Storia e Letteratura.

Varsori, A.(2009). Stati Uniti e Gran Bretagna: la questione della difesa europea dopo lo scoppio della guerra di Corea.In Ballini, P.L.(Ed.), La Comunità Europea di Difesa (CED) (pp. 1-34). Soveria Mannelli: Rubbettino. 